\title{
Prediction Accuracy for Projectwide Evapotranspiration Using Crop Coefficients and Reference Evapotranspiration
}

\author{
Richard G. Allen, M.ASCE${ }^{1}$; Albert J. Clemmens, M.ASCE²; Charles M. Burt, M.ASCE ${ }^{3}$; \\ Ken Solomon, M.ASCE${ }^{4}$; and Tim O'Halloran ${ }^{5}$
}

\begin{abstract}
The Imperial Irrigation District is a large irrigation project in the western United States having a unique hydrogeologic structure such that only small amounts of deep percolation leave the project directly as subsurface flows. This structure is conducive to relatively accurate application of a surface water balance to the district, enabling the determination of crop evapotranspiration $\left(\mathrm{ET}_{c}\right)$ as a residual of inflows and outflows. The ability to calculate $\mathrm{ET}_{c}$ from discharge measurements provides the opportunity to assess the accuracy and consistency of an independently applied crop coefficient—reference evapotranspiration $\left(K_{c} \mathrm{ET}_{0}\right)$ procedure integrated over the project. The accuracy of the annual crop evapotranspiration via water balance estimates was $\pm 6 \%$ at the $95 \%$ confidence level. Calculations using $K_{c}$ and $\mathrm{ET}_{0}$ were based on the FAO-56 dual crop coefficient approach and included separate calculation of evaporation from precipitation and irrigation events. Grass reference $\mathrm{ET}_{0}$ was computed using the CIMIS Penman equation and $\mathrm{ET}_{c}$ was computed for over 30 crop types. On average, $K_{c}$-based ET computations exceeded $\mathrm{ET}_{c}$ determined by water balance (referred to as $\mathrm{ET}_{c} \mathrm{wB}_{\text {) }}$ ) by $8 \%$ on an annual basis over a 7 year period. The $8 \%$ overprediction was concluded to stem primarily from use of $K_{c}$ that represents potential and ideal growing conditions, whereas crops in the study area were not always in full pristine condition due to various water and agronomic stresses. A $6 \%$ reduction to calculated $K_{c}$-based ET was applied to all crops, and a further $2 \%$ reduction was applied to lower value crops to bring the project-wide ET predicted by $K_{c}$-based ET into agreement with $\mathrm{ET}_{c}$ wB. The standard error of estimate (SEE) for annual ET for the entire project based on $K_{c}$, following the reduction adjustment, was $3.4 \%$ of total annual $\mathrm{ET}_{c}$, which is considered to be quite good. The SEE for the average monthly $\mathrm{ET}_{c}$ was $15 \%$ of average monthly $\mathrm{ET}_{c}$. A sensitivity analysis of the computational procedure for $K_{c}$ showed that relaxation from using the FAO-56 dual $K_{c}$ method to the more simple mean (i.e., single) $K_{c}$ curve and relaxation of specificity of planting and harvest dates did not substantially increase the projectwide prediction error The use of the mean $K_{c}$ curves, where effects of evaporation from wet soil are included as general averages, predicted $5 \%$ lower than the dual method for monthly estimates and $8 \%$ lower on an annual basis, so that no adjustment was required to match annual ET derived from water balance. About one half of the reduction in estimates when applying the single (or mean) $K_{c}$ method rather than the dual $K_{c}$ method was caused by the lack of accounting for evaporation from special irrigations during the off season (i.e., in between crops).
\end{abstract}

CE Database subject headings: Model accuracy; Evapotranspiration; Irrigation districts; Project evaluation; Crops; Water balance.

\section{Introduction}

The common approach to quantify consumptive use of water by crops within irrigation projects is the $K_{c}$-based procedure, where reference evapotranspiration $\left(\mathrm{ET}_{0}\right)$ is computed for a grass or

\footnotetext{
${ }^{1}$ Professor, Univ. Idaho, Kimberly, ID 83341. E-mail: rallen@ uidaho.edu

${ }^{2}$ Director, U.S. Water Conservation Laboratory, Phoenix, AZ 85040.

${ }^{3}$ Professor and Chairman of the Board, Irrigation Training and Research Center, California Polytechnic State Univ., San Luis Obispo, CA 93407.

${ }^{4}$ Professor and Chairman, BioResource and Agricultural Engineering Dept., California Polytechnic State Univ., San Luis Obispo, CA 93407.

${ }^{5}$ Water Master, The Kings River Water Association, 4886 E. Jensen Ave., Fresno, CA 93725; formerly, Imperial Irrigation District.
}

alfalfa reference crop and is then multiplied by an empirical crop coefficient $\left(K_{c}\right)$ to produce an estimate of $\mathrm{ET}_{c}$. The $K_{c}$-based approach is primary for predicting water consumption from irrigation projects because it is generally difficult to determine $\mathrm{ET}_{c}$ as a residual from a water balance computation (Burt et al. 1997; Molden and Sakthivadivel 1999; Droogers and Bastiaanssen 2002). Deep percolation components from irrigation projects are difficult to measure or predict, causing large uncertainty in computed $\mathrm{ET}_{c}$ (Clemmens and Burt 1997; Gochis and Cuenca 2000; Szilagyi et al. 2001).

There can be considerable uncertainty in $K_{c}$-based ET prediction due to uncertainty in quality and representativeness of weather data for the $\mathrm{ET}_{0}$ estimate and uncertainty regarding similarity in physiology and morphology between specific crops and varieties in an area and the crop for which the $K_{c}$ was originally derived. In addition, there are uncertainties regarding planting, growth stage, and harvest dates, uncertainty in effectiveness of precipitation, uncertainties in adequacy, uniformity and timing of irrigation, and uncertainties in the agronomic health and vigor of the crop relative to that implied in the $K_{c}$ value. All of these uncertainties contribute to uncertainty in the resulting $\mathrm{ET}_{c}$ esti- 
mate and uncertainty as to whether the $K_{c}$-based ET calculation will over or underpredict actual $\mathrm{ET}_{c}$.

The Imperial Irrigation District (IID) is a large irrigation project located in southern California, north of the border with Mexico. The district derives its irrigation water from the Colorado River via the All-American Canal, and produces high value vegetable and field crops year round. The alluvium underlying IID has a large clay component at depth having very low hydraulic conductivity. The low hydraulic conductivity of deep clay deposits tends to force deep percolation laterally to surface drains, often with the assistance of subsurface drains, so that only very small amounts of deep percolation (less than $0.1 \%$ of canal inflow) leave the project directly as subsurface flows. Essentially all deep percolation and drainage waters flow to the Salton Sea in drains and rivers that can be readily measured. The geohydrology, in combination with the very detailed and excellent measurement records by the Imperial Irrigation District, provides for accurate computation of a surface water balance for the project, enabling $\mathrm{ET}_{c}$ to be determined as a residual of inflows and outflows. The IID is unique in this regard, and the availability of $\mathrm{ET}_{c}$ from the water balance has provided the opportunity to assess the accuracy and consistency of an independently applied $K_{c}$-based ET procedure.

\section{FAO-56 Dual Crop Coefficient Procedure}

The FAO-56 "dual" crop coefficient procedure (Allen et al. 1998, 2005) provides the opportunity for precise estimation of ET by calculating evaporation from precipitation and irrigation events separately from ET computed for crops having dry soil surface. Thus, impacts of water holding characteristics of soils, irrigation system type and wetting frequency are better captured. The FAO-56 dual procedure is fully described in Allen et al. (1998, 2005). The method was applied to the study area to capture impacts of both in-season and off-season wetting events on the evaporative component of water consumption. Extensions by Allen et al. (2005) for predicting evaporation during Stage 3 drying in cracking soils and root extraction of water from the surface soil layer were applied.

Briefly, the FAO-56 dual crop coefficient procedure consists of splitting $K_{c}$ into two separate coefficients, one representing essentially only crop transpiration, i.e., the basal crop coefficient $\left(K_{\mathrm{cb}}\right)$, and one representing soil evaporation $\left(K_{e}\right)$

$$
\mathrm{ET}_{c}=\left(K_{s} K_{\mathrm{cb}}+K_{e}\right) \mathrm{ET}_{0}
$$

where $K_{s}=$ coefficient describing any reductions to $K_{\mathrm{cb}}$ resulting from water or salinity stress $\left(0 \leqslant K_{s} \leqslant 1.0\right)$. The basal crop coefficient is the ratio of the crop evapotranspiration to the reference evapotranspiration $\left(\mathrm{ET}_{c} / \mathrm{ET}_{0}\right)$ when the soil surface is dry, but transpiration is occurring at a potential rate, i.e., water is not limiting transpiration. The $K_{\mathrm{cb}} \times \mathrm{ET}_{0}$ product includes a residual diffusive evaporation component supplied by soil water below the dry surface and by soil water from beneath dense vegetation.

The FAO-56 has summarized general values for $K_{\mathrm{cb}}$ during the initial period, during the midseason period $\left(K_{\mathrm{cb} \text { mid }}\right)$, and at the end of season $\left(K_{\mathrm{cb} \text { end }}\right)$. These values represent a standard climate having mean daily minimum relative humidity $\left(\mathrm{RH}_{\text {min }}\right)$ equal to $45 \%$ and mean daily wind speed measured at $2 \mathrm{~m}\left(u_{2}\right)$ equal to $2 \mathrm{~m} \mathrm{~s}^{-1}$. When mean weather conditions differ from the standard climate, $K_{\mathrm{cb} \min }$ and $K_{\mathrm{cb} \text { end }}$ are adjusted using $\mathrm{RH}_{\min }$ and $u_{2}$ as described in Allen et al. (1998, 2005). This practice was followed in this study using average $\mathrm{RH}_{\min }$ and $u_{2}$ during the midseason period of each crop.

The dual procedure of FAO-56 requires specification of the fraction of surface wetted by irrigation $\left(f_{w}\right)$ to constrain the estimation of evaporation. The estimation of $K_{e}$ in the calculation procedure required a daily water balance for the exposed and wetted soil fraction $f_{e w}$ of the surface soil layer. This fraction is a function of $f_{w}$ and the fraction of ground covered by vegetation as described by Allen et al. (1998, 2005).

\section{Study Area}

\section{Climate}

The Imperial Valley of California has a desert climate known for high summer temperatures, warm winters, and low rainfall. The annual mean temperature is $23^{\circ} \mathrm{C}\left(73^{\circ} \mathrm{F}\right)$, annual mean daily maximum temperature is $35.5^{\circ} \mathrm{C}$ and annual mean daily minimum temperature is $13.5^{\circ} \mathrm{C}$. The highest monthly mean temperature recorded was $35.5^{\circ} \mathrm{C}$ in August 1969 and the lowest monthly mean temperature recorded was $5.7^{\circ} \mathrm{C}$ in February 1939. The highest daily maximum temperature recorded was $49.4^{\circ} \mathrm{C}$ $\left(121^{\circ} \mathrm{F}\right)$ on July 28,1995 . The 85 year average annual rainfall from 1914 to 1998 was only $74 \mathrm{~mm}$ (2.93 in.), with June being the driest month. The year 1939 is the record wet year with $216 \mathrm{~mm}$. The lowest annual rainfall was $4 \mathrm{~mm}$ in 1956 (IID 2003). Average annual grass reference ET for the IID service area over the 1985-2002 period is $1,910 \mathrm{~mm}$ with a low of $1,780 \mathrm{~mm}$ in 1991 and a high of 2,140 $\mathrm{mm}$ in 1989 .

Air temperature and precipitation data have been collected at about ten volunteer weather stations in the IID service area since the first part of the 20th century. Since 1983, solar radiation, air temperature, wind, and humidity data have been reported hourly by the California Irrigation Management Information System (CIMIS), beginning with Calipatria in 1983, Seeley in 1987, and Meloland in 1989. Locations of these three stations are indicated in Fig. 1.

\section{Delivery System}

The IID receives an average of 3.8 billion $\mathrm{m}^{3}$ (3.1 million acre-feet) of water each year from the Colorado River via the All-American Canal (IID 2003). The water delivery system and service area and drainage rivers are shown in Fig. 1. Three main canals, the East Highline, Central Main, and Westside Main, deliver water from the All-American Canal to laterals laid out on a relatively uniform grid. The IID operates and maintains approximately 5,600 delivery gates on more than $2,300 \mathrm{~km}(1,440 \mathrm{mi}$.) of laterals, $370 \mathrm{~km}$ (230 mi.) of main canals and the $130 \mathrm{~km}$ (82 mi.) All-American Canal. The IID maintains approximately $2,260 \mathrm{~km}$ (1,406 mi.) of drainage ditches used to collect surface runoff and subsurface drainage from $51,800 \mathrm{~km}(32,230 \mathrm{mi}$.) of tile drains underlying 187,000 ha $(462,202$ acres $)$ of farmland (IID 2003). Total land area within the IID is 430,000 ha $(1,062,000$ acres $)$, including nonagricultural lands. Most drainage ditches ultimately discharge water into either the Alamo River or New River, where it passes to the Salton Sea (Fig. 1).

The extensive gravity flow drainage system of IID provides a drainage outlet for each governmental subdivision of approximately 65 ha and, as such, the drains generally parallel canals. 


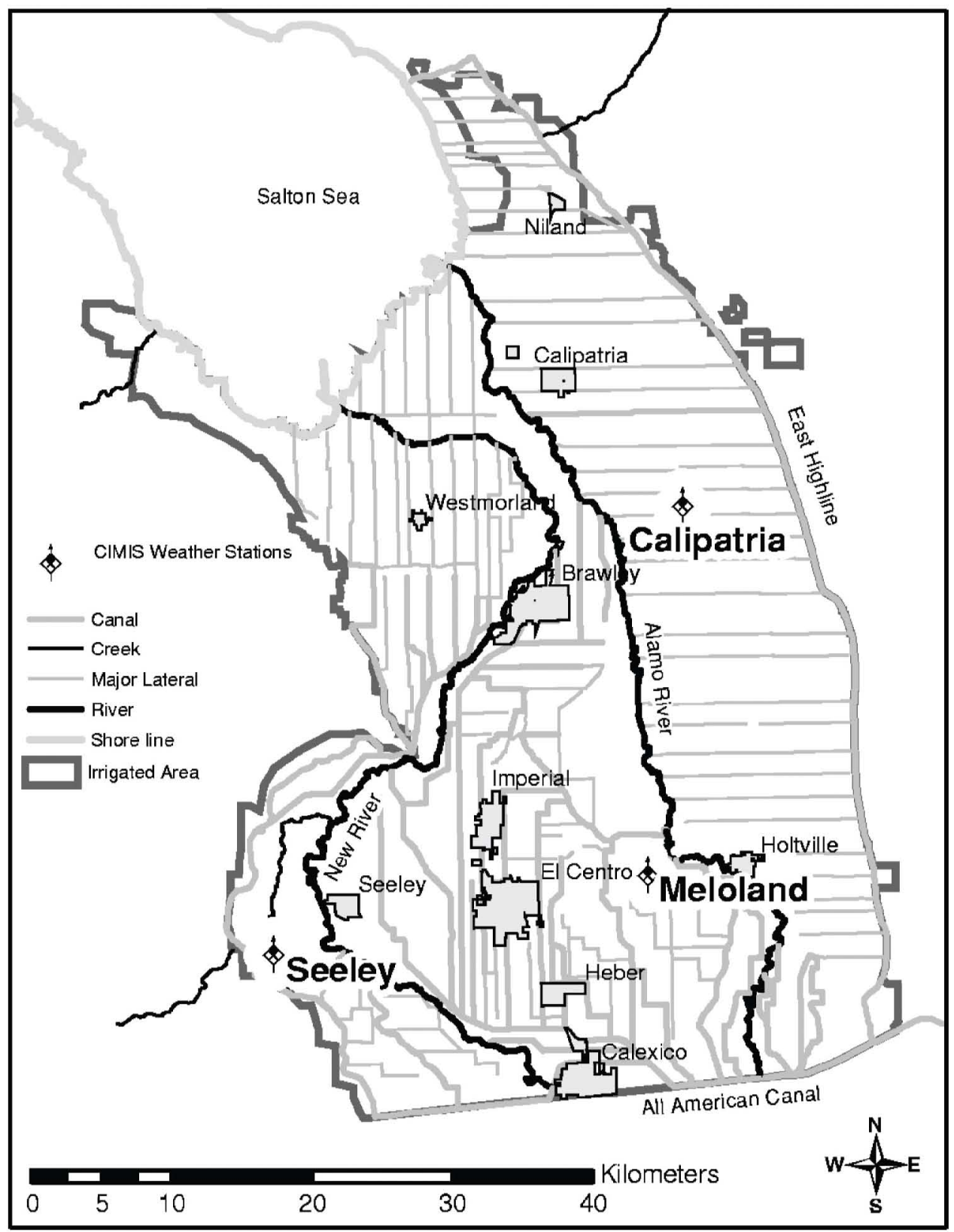

Fig. 1. Map of imperial irrigation district showing major canals, rivers, and service area and locations of California Irrigation Management Information System stations used to compute reference evapotranspiration

The district maintains the water levels in surface drains at generally $2-3 \mathrm{~m}$ depth or deeper below ground surface. In many areas, sumps with pumps lift drainage water into surface drains for discharge to the rivers or sea. The full supply of water to IID is from the Colorado River and as such contains moderate levels of salt that require periodic leaching of soils for control. Salinity of Colorado River water diverted by IID averaged $1.23 \mathrm{dS} \mathrm{m}^{-1}$ during the 1990-1996 study period.

\section{Geology}

The IID service area lies within the Salton trough which is a large topographic depression and deep closed basin. Inundations of either seawater or Colorado River into the trough over geologic time have created interlayering of lacustrine and alluvial sediments. The present day service area of IID is within the shorelines of the prehistoric Lake Cahuilla and soils in the central area of the district were developed from lakebed materials that are more than $1000 \mathrm{~m}$ thick. These materials are predominately clay and silt. Soils in the lower-elevation portions of the district exhibit cracking properties. Soils along the western and eastern margins of the service area formed from alluvium and wind deposits and are more coarse textured (Zimmerman 1981).

Detailed information on hydrology and geology of the Imperial Valley are given in Loeltz et al. (1975) and Setmire et al. (1993). Because of the variation over time in inundation and distribution of sediment and alluvium, sediments in the IID service area comprise heterogeneous strata that vary in thickness, texture and continuity. Surface soils are generally underlain by thick dense clay deposits having very low permeability (Setmire et al. 1993). Because of the layering, the flow components of shallow 


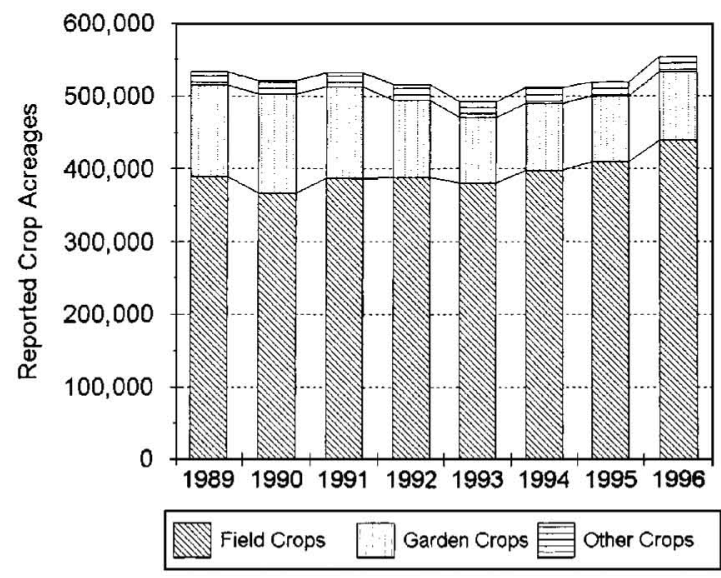

Fig. 2. General acreages of crops in the Imperial Irrigation District during study period (from WST 1998)

groundwater are primarily horizontal. The extensive system of subsurface drains in IID assist in directing groundwater into surface drains.

Relatively little inflow of groundwater (less than 25 million $\mathrm{m}^{3}$ year ${ }^{1}$ or $0.6 \%$ of irrigation inflows) originates from outside the district (IID 2002). Only 2.5 million $\mathrm{m}^{3}$ year $^{-1}(0.06 \%$ of irrigation inflows) of groundwater flows into the Salton Sea (IID 2002), thus a surface water balance of irrigation, drain and river inflows, and outflows and precipitation allows for a relatively accurate determination of ET.

\section{Crops and Irrigation}

More than 40 types of crops are grown in the Imperial Valley, ranging from winter vegetables grown for the fresh market to field crops of alfalfa hay, sugar beets, corn, wheat, Bermuda grass, and Sudan grass. Annual acreage summaries of field, garden, and other crops for the period of this study are shown in Fig. 2. Approximately $8,000-35,000$ ha $(20,000-90,000$ acres $)$ in IID are double cropped within any calendar year. The "other" crop category in Fig. 2 is summarized in Table 1.

The primary method of irrigation is graded border with run lengths of typically $400 \mathrm{~m}$. Irrigation uniformity is generally high due to the high clay content soils under much of the irrigated land. Vegetable crops planted during fall are often irrigated by solid set sprinkler for germination and then transitioned to surface irrigation. Many crops are bedded within border strips to create a type of furrow-irrigated system.

\section{Application to Study Area}

The Imperial Irrigation District is recognized nationally and internationally for its broad range and high quality of data collection and record keeping. Table 1 lists the major crop categories in IID and summarizes general areas planted to field crops, vegetables, and other crops. Evapotranspiration for the more than 30 crop types in the Imperial Irrigation District was evaluated for a 7 year period (1990-1996), with $K_{c}$-based calculations extending from December of one year into January of the following year for continuity. Calculation of $K_{c}$ and $\mathrm{ET}_{c}$ was done daily. One of the data summaries available to this study was the distribution of planting and harvest dates by crop versus time, recorded for each year. These distributions were based on observations by district employees (zanjeros) on a field-by-field basis and provided valuable information on average starting and ending dates for growing seasons for each crop type. The distributions of lengths of cropping periods were found to be normally distributed for most crops so that mean dates could be used for both planting and harvest. One crop coefficient curve per crop type was used to represent all crops of that type across the district each year, based on the mean planting and harvest dates.

The specification of irrigation dates was important for predicting quantities of evaporation from wet soil. In the application of the dual $K_{c}$ method to IID, it was not possible to simulate the irrigation events and associated evaporation for fields due to the large number of fields and unknown timings of irrigation. Therefore, general irrigation dates were predicted for each crop according to a daily soil water balance and assumed management allowed depletion levels and soil characteristics. The irrigation dates were specific to each crop and each year. Irrigation dates were manually specified for alfalfa crops, with two irrigations per cutting cycle. Alfalfa hay was assumed to follow a 30 day cutting cycle during spring, summer, and fall. Irrigation was terminated between three and ten days before harvest of most crops as summarized in Table 1. For seven crops (wheat, cotton, sudan, sugar beets, onions, rye, alfalfa seed), irrigation was terminated earlier to follow local cultural practices that improve harvestibility.

Many of the soils in IID are fine-textured with large amounts of montmorillinite clay, causing them to crack during drying. This cracking exposes progressively greater depths of the soil to drying by evaporation between irrigations. Two general soil types (heavy, that cracked substantially during drying and light) were used in the daily soil water balances for crop root zones. These soil groups are summarized in Table 2. Average available water amounts in Table 2 follow definitions and usage described in Allen et al. (2005). Stage 3 drying, where the evaporation process is extended in time due to the opening of cracks, was applied to the heavy soils as described in Allen et al. (2005). Vegetable (garden) crops were presumed to be planted predominately in the light soils and field crops in the heavy soils.

The stress factor $K_{s}$ in Eq. (1) was invoked during calculation when soil water became less than the specified threshold. Stress was predicted following irrigation termination near ends of season and occasionally for alfalfa for which irrigation dates were manually specified. Thresholds, in terms of percent available soil water, were specified for each crop for both the initial period and for the balance of the growing period.

The amount of rainfall infiltrated was predicted by subtracting rainfall lost by runoff. In this application, rainfall runoff was predicted using the Natural Resources Conservation Service (NRCS) curve number procedure (SCS 1972; Hawkins et al. 1985).

Values for $K_{\mathrm{cb}}$ were taken from FAO-56 (Allen et al. 1998) and were compared with $K_{c}$ values for the local area published in Univ. of California publications (Snyder et al. 1989a,b). The FAO-56 values for $K_{\mathrm{cb}}$ for some crops were adjusted to improve consistency with California $K_{c}$ values, with allowance for differences in $K_{c}$ basis (dual versus single). The minor adjustments to California values were done to be consistent with current practice in California and for consistency with using $\mathrm{ET}_{0}$ that was computed in this study using the CIMIS Penman equation. Values for $K_{\mathrm{cb}}$ are presented in Table 1 for the crop types modeled. Where different from FAO-56, the FAO-56 values are listed in parentheses. We do not suggest that the FAO-56 values be changed for applications to other areas. In Table 1 , the $K_{\mathrm{cb}}$ pre and $K_{\mathrm{cb}}$ after values apply to periods preceding planting and following harvest of crops. In most cases, these values were set to zero in the dual 
Table 1. Basal Crop Coefficients $\left(K_{\mathrm{cb}}\right)$, Mean Dates, and Irrigation Wetting Characteristics Used in Dual $K_{c}$ Application to Imperical Irrigation District

\begin{tabular}{|c|c|c|c|c|c|c|c|c|c|c|c|}
\hline Crop & $K_{\mathrm{cb} \text { pre }}$ & $K_{\mathrm{cb} \text { ini }}$ & $K_{\mathrm{cb} \text { mid }}$ & $K_{\mathrm{cb} \text { end }}$ & $K_{\mathrm{cb} \text { after }}$ & $\begin{array}{c}\text { Mean } \\
\text { planting } \\
\text { date (month/day) }\end{array}$ & $\begin{array}{c}\text { Mean } \\
\text { harvest } \\
\text { date } \\
\text { (month/day) }\end{array}$ & $\begin{array}{c}\text { Irrigation } \\
\text { termination } \\
\text { (days } \\
\text { before } \\
\text { harvest) }\end{array}$ & $\begin{array}{c}\text { Number } \\
\text { offseason } \\
\text { irrigations }\end{array}$ & $\begin{array}{l}\text { Sprinkling } \\
\text { for } \\
\text { emergence }\end{array}$ & $\begin{array}{c}\text { Fraction } \\
\text { of } \\
\text { surface } \\
\text { wetted } \\
\left(f_{w}\right) \\
\end{array}$ \\
\hline Field crops & \multicolumn{11}{|c|}{ Approximately 160,000 ha $(400,000$ acres $)$} \\
\hline Alfalfa hay & 0 & 0.30 & 1.15 & 1.10 & 0 & $2 / 1$ & $10 / 15$ & $-^{\mathrm{a}}$ & - & - & 0.8 \\
\hline Alfalfa-winter ${ }^{\mathrm{d}}$ & 0 & 0.30 & 1.00 & 0.95 & 0 & $10 / 15$ & $2 / 1$ & - & - & - & 0.8 \\
\hline Alfalfa-new ${ }^{\mathrm{d}}$ & 0 & 0.15 & 0.80 & 0.50 & 0 & $10 / 15$ & $2 / 1$ & - & 2 & - & 0.8 \\
\hline Alfalfa—seed & 0 & 0.30 & $\begin{array}{l}0.80^{\mathrm{c}} \\
(0.45)\end{array}$ & $\begin{array}{l}0.70^{\mathrm{c}} \\
(0.45)\end{array}$ & 0 & $5 / 15$ & $8 / 15$ & - & - & - & 0.8 \\
\hline $\begin{array}{l}\text { Bermuda—spring } \\
\text { (seed) }\end{array}$ & 0 & 0.15 & 0.85 & 0.60 & 0 & $3 / 15$ & $6 / 15$ & - & - & - & 1.0 \\
\hline Bermuda-summer & 0 & 0.50 & 0.95 & 0.80 & 0 & $6 / 15$ & $11 / 1$ & 7 & - & - & 1.0 \\
\hline Cotton & 0 & 0.15 & 1.15 & 0.40 & 0 & $3 / 10$ & $10 / 17$ & 45 & 1 & - & 0.4 \\
\hline Oats and barley & 0 & 0.15 & 1.10 & 0.15 & 0 & $10 / 7$ & $5 / 2$ & 20 & 1 & - & 0.8 \\
\hline Rye grass & 0 & 0.85 & 1.00 & $\begin{array}{l}0.90^{\mathrm{c}} \\
(0.95)\end{array}$ & 0 & $10 / 10$ & $6 / 9$ & 45 & 1 & - & 1.0 \\
\hline Sudan grass & 0 & 0.30 & 1.10 & 1.05 & 0 & $4 / 12$ & $10 / 12$ & 30 & - & - & 1.0 \\
\hline Sugar beets & 0 & 0.15 & 1.15 & $\begin{array}{l}0.40^{\mathrm{c}} \\
(0.50)\end{array}$ & 0 & $9 / 22$ & $6 / 19$ & 25 & 2 & Yes & 0.85 \\
\hline Wheat & 0 & 0.15 & 1.10 & 0.15 & 0 & $12 / 12$ & $6 / 5$ & 30 & 1 & 一 & 0.8 \\
\hline Vegetable crops & \multicolumn{11}{|c|}{ Approximately 40,000 ha $(100,000$ acres $)$} \\
\hline Broccoli & 0 & 0.15 & 0.95 & $\begin{array}{l}0.90^{\mathrm{c}} \\
(0.85)\end{array}$ & 0 & $9 / 30$ & $2 / 12$ & 3 & 2 & Yes & 0.7 \\
\hline Cabbage & 0 & 0.15 & 0.95 & $\begin{array}{l}0.90^{\mathrm{c}} \\
(0.85)\end{array}$ & 0 & $9 / 17$ & $3 / 5$ & 3 & 2 & Yes & 0.7 \\
\hline Carrots & 0 & 0.15 & $\begin{array}{l}1.00^{\mathrm{c}} \\
(0.95)\end{array}$ & $\begin{array}{l}0.90^{\mathrm{c}} \\
(0.85)\end{array}$ & 0 & $10 / 12$ & $4 / 26$ & 10 & 1 & Yes & 0.8 \\
\hline Cauliflower & 0 & 0.15 & 0.95 & $\begin{array}{l}0.80^{\mathrm{c}} \\
(0.85)\end{array}$ & 0 & $9 / 19$ & $2 / 6$ & 3 & 2 & Yes & 0.6 \\
\hline Corn, ear & 0 & 0.15 & $\begin{array}{l}1.10^{\mathrm{c}} \\
(1.15)\end{array}$ & 0.50 & 0 & $1 / 21$ & $6 / 8$ & 5 & 2 & - & 0.7 \\
\hline Lettuce (two crops) & 0 & 0.15 & 0.90 & 0.90 & 0 & $10 / 9$ & $2 / 14$ & 3 & 1 & Yes & 0.7 \\
\hline Cantaloupes (fall) & 0 & 0.15 & 0.75 & 0.50 & 0 & $8 / 26$ & $12 / 31$ & 10 & 2 & Yes & 0.3 \\
\hline Cantaloupes (spring) & 0 & 0.15 & 0.75 & 0.50 & 0 & $2 / 7$ & $6 / 21$ & 10 & 2 & - & 0.3 \\
\hline $\begin{array}{l}\text { Honeydew and } \\
\text { water melon }\end{array}$ & 0 & 0.15 & $\begin{array}{l}1.00^{\mathrm{c}} \\
(0.95)\end{array}$ & $\begin{array}{l}0.85^{\mathrm{c}} \\
(0.70)\end{array}$ & 0 & $2 / 1$ & $6 / 23$ & 5 & 1 & Yes & 0.3 \\
\hline Onions & 0 & 0.15 & 0.95 & 0.65 & 0 & $10 / 19$ & $6 / 2$ & 21 & 2 & Yes & 0.8 \\
\hline Onion seed & 0 & 0.15 & $\begin{array}{l}1.00^{\mathrm{c}} \\
(1.05)\end{array}$ & 0.70 & 0 & $9 / 24$ & $6 / 23$ & 10 & 2 & Yes & 0.8 \\
\hline Tomatoes & 0 & 0.15 & $\begin{array}{l}1.15^{\mathrm{c}} \\
(1.10)\end{array}$ & $\begin{array}{l}0.55^{\mathrm{c}} \\
(0.60)\end{array}$ & 0 & $1 / 25$ & $6 / 28$ & 10 & - & (drip) & 0.2 \\
\hline Potatoes & 0 & 0.15 & 1.10 & 0.65 & 0 & $12 / 1$ & $4 / 17$ & 3 & 2 & (sprinkled) & 1.0 \\
\hline Other & \multicolumn{11}{|c|}{ Approximately 8,000 ha $(20,000$ acres $)$} \\
\hline Asparagus & 0.15 & 0.15 & 0.90 & $\begin{array}{l}0.50^{\mathrm{c}} \\
(0.20)\end{array}$ & 0.15 & $12 / 1$ & $12 / 1$ & 15 & - & - & 0.7 \\
\hline Citrus & 0 & $\begin{array}{c}0.70^{\mathrm{c}} \\
(0.65)\end{array}$ & $\begin{array}{c}0.90^{\mathrm{c}} \\
(0.60)\end{array}$ & $\begin{array}{l}0.70^{\mathrm{c}} \\
(0.65)\end{array}$ & 0 & $1 / 1$ & $1 / 1$ & - & - & - & 0.8 \\
\hline Duck ponds ${ }^{\mathrm{e}}$ & 0.40 & 0.40 & 0.70 & 0.40 & 0.40 & $8 / 15$ & $4 / 20$ & No irrigation & - & - & 0.3 \\
\hline Jojoba $^{\mathrm{d}}$ & 0 & 0.40 & 0.50 & 0.40 & 0 & $1 / 1$ & $1 / 1$ & - & - & - & 0.2 \\
\hline Fish farms ${ }^{e}$ & 0 & 0.70 & 0.70 & 0.70 & 0 & $1 / 1$ & $1 / 1$ & No irrigation & - & - & 0.4 \\
\hline Peach trees & 0 & 0.45 & 0.85 & 0.60 & 0 & $1 / 1$ & $1 / 1$ & - & - & - & 0.8 \\
\hline Permanent pasture & - & 0.35 & 0.85 & 0.70 & - & $3 / 1$ & $11 / 1$ & - & - & - & 1.0 \\
\hline No crop & 0.15 & 0.50 & 0.30 & 0.50 & 0.15 & $1 / 1$ & $1 / 1$ & No irrigation & - & - & 1.0 \\
\hline
\end{tabular}

${ }^{a}$ Alfalfa hay was irrigated twice per cutting cycle during the nonwinter months, at 12 and 24 days following cutting. Alfalfa hay had eight cutting cycles.

${ }^{\mathrm{b}}$ Alfalfa for seed was irrigated four times during the seed producing period.

${ }^{\mathrm{c}}$ Value is different from FAO-56 Table 17 to increase agreement with University of California publications. Value in parentheses is from FAO-56.

${ }^{\mathrm{d}}$ Crop not in FAO-56.

${ }^{\mathrm{e}}$ Duck ponds are flooded areas of native wetland vegetation used for hunting of wildfowl. Fish farms contain series of open channels separated by bare soil. 


\begin{tabular}{|c|c|c|c|c|c|c|c|}
\hline Soils name & $\begin{array}{c}\text { IID } \\
\text { service area } \\
(\%)\end{array}$ & $\begin{array}{l}\text { Available } \\
\text { water } \\
(0-300 \mathrm{~mm}) \\
\left(\mathrm{mm} \mathrm{mm}^{-1}\right)\end{array}$ & $\begin{array}{c}\text { Available } \\
\text { water } \\
(>300 \mathrm{~mm} \mathrm{depth})^{\left(\mathrm{mm} \mathrm{mm}^{-1}\right)}\end{array}$ & $\begin{array}{c}\text { Available } \\
\text { water in } K_{c} \\
\text { calculations } \\
\left(\mathrm{mm} \mathrm{mm}^{-1}\right)\end{array}$ & $\begin{array}{l}\text { Readily } \\
\text { available } \\
\text { water for } \\
\text { evaporation } \\
\text { during } \\
\text { Stage 1 } \\
(\mathrm{mm})\end{array}$ & $\begin{array}{c}\text { Total } \\
\text { available } \\
\text { water for } \\
\text { evaporation } \\
\text { during } \\
\text { Stages } 1 \text { and } 2 \\
(\mathrm{~mm})\end{array}$ & $\begin{array}{c}\text { Total } \\
\text { available } \\
\text { water for } \\
\text { evaporation } \\
\text { during } \\
\text { Stages } 1,2 \text {, and } 3 \\
(\mathrm{~mm})\end{array}$ \\
\hline \multicolumn{8}{|l|}{ Heavy soils } \\
\hline Imperical silty clay & 44 & $0.17-0.35$ & $0.17-0.35$ & & & & \\
\hline Glenbar clay loam & 15 & $0.13-0.15$ & $0.16-0.18$ & 0.20 & 10 & 50 & 100 \\
\hline Holtville silty clay & 15 & $0.17-0.25$ & $0.17-0.25$ & & & & \\
\hline \multicolumn{8}{|l|}{ Light soils } \\
\hline Meloland fine sand & 8 & $0.15-0.25$ & $0.07-0.20$ & & & & \\
\hline Antho loamy fine sand & 8 & $0.08-0.09$ & $0.08-0.12$ & 0.14 & 6 & 22 & No Stage 3 \\
\hline Indio loam & $\frac{6}{96}$ & $0.13-0.20$ & $0.16-0.20$ & & & & \\
\hline
\end{tabular}

Note: IID=Imperial Irrigation District.

procedure to allow the soil surface to dry to zero $\mathrm{ET}_{c}$ during long periods with no wetting.

Relative lengths for the four growth stages of the FAO-style curves (Doorenbos and Pruitt 1977; Allen et al. 1998) were derived from FAO-56 tables, with some adjustment based on local literature and observation. In all cases, the total length of growing season was computed using actual average planting and harvest dates reported to the district for each year. Lengths of the four individual stages of the FAO-style curves were increased or decreased proportionate to the total length of season.

In the $K_{c}$-based application, each crop was presumed to follow itself in rotation to preserve consistency in cropped acreage and soil water balance. $\mathrm{ET}_{c}$ was computed for the entire calendar year and included periods between crops. ET predicted for fallowed land (receiving precipitation, only) was subtracted from the ET total for the study area in proportion to the amount of double cropping to correct for double counting of off-season ET between crops. Daily $\mathrm{ET}_{c}$ calculations were summed monthly and then multiplied by crop acreages provided by the project for each crop and year to obtain $\mathrm{ET}_{c}$ as a volume over the study area.

Reference evapotranspiration $\mathrm{ET}_{0}$, was computed using the CIMIS Penman method (Pruitt et al. 1987; Snyder et al. 1989a,b) to be consistent with local usage. Weather data from three automated weather stations in the study area were intensely screened using integrity assessment procedures described by Allen (1996), Allen et al. (1998), and ASCE (2002). ET 0 values were recomputed following quality control analyses to correct for adjustments made to weather data during the analyses and to correct for problems perceived in net radiation $\left(R_{n}\right)$ computed by CIMIS (WST 1998). Prior to $1989-1990, R_{n}$ reported by CIMIS were measured values. Following $1989, R_{n}$ was computed by CIMIS using measured solar radiation. However, $R_{n}$ computations by CIMIS averaged $13 \%$ lower than prior $R_{n}$ measurements. Calculation of $R_{n}$ based on the procedure of FAO-56 (Allen et al. 1998) over the period of record indicated there should be no downward shift in reported $R_{n}$. The FAO-56 method for $R_{n}$ was therefore applied during recalculation of CIMIS ET $\mathrm{ET}_{0}$ to provide consistency in $\mathrm{ET}_{0}$ calculation. A weighted average daily $\mathrm{ET}_{0}$ for the district was calculated based on proximity of service area to each station using the polygon method, where weighting was $47 \%$ for Calipatria, 18\% for Seeley, and 35\% for Meloland (WST 1998).

Evapotranspiration by water balance $\left(\mathrm{ET}_{c} \mathrm{wB}_{\mathrm{B}}\right)$ for irrigated ag- riculture in the study area was computed by WST (1998) as

$\begin{aligned} \mathrm{ET}_{c \mathrm{WB}}= & \text { inflows to project }- \text { surface outflows from project } \\ & - \text { subsurface outflows }+ \text { precipitation }-\mathrm{ET}_{\text {nonag.lands }}-\Delta S\end{aligned}$

where $\mathrm{ET}_{\text {nonag.lands }}=\mathrm{ET}$ from nonfarmed portions of the study area, including cities, roadways, river corridors, canals, drains, and unfarmed areas. The change in projectwide soil water storage from month to month $(\Delta S)$ was applied to correct the monthly and annual surface water balance calculations. The $\Delta S$ was computed during the $K_{c}$-based process by calculating differences in 15 day running averages of soil water contents computed for all crops, centered on the ends of months. Estimated $\Delta S$ over the study area was large in some months, for example, during periods of preirrigation prior to planting of wheat crops in fall, and in some cases, changed values for monthly $\mathrm{ET}_{c}$ wB by as much as $10 \%$.

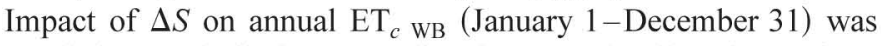
small due to similarity to predicted year end soil moisture from year to year. Water storage within the irrigation project includes groundwater and vadose water that can vary from month to month due to the tendency for potentially slow rates of subsurface drainage and variation in leaching and deep percolation among months. Changes in subsurface water storage were not considered in the monthly $\Delta S$ due to lack of measurement data. Consideration of these changes would have increased estimated $\mathrm{ET}_{c}$ WB for some months and reduced it for others by some unquantified amount.

Spillage and seepage losses from the water delivery system of IID enter drainage and/or river systems before flow to the Salton Sea. Therefore, these losses do not enter into Eq. (2) because they are measured as outflow from the study area. Evaporation losses from water surfaces and phreatophytes were determined using reported areas and $K_{c}$ values from FAO-56. Evapotranspiration from cities (part of $\mathrm{ET}_{\text {nonag.lands }}$ ) was determined from delivery records and use of return flow factors. Distribution system evaporation losses and ET from cities was a relatively small component of the total water balance, totaling less than $6 \%$ of district ET. Uncertainty in these estimates contributed only $8 \%$ to total variance (error) in the final $\mathrm{ET}_{c}$ wB estimates (representing ET from agricultural fields). 
Accuracy of inflow and outflow measurements in IID, including inflow from the All-American Canal and New River and outflows of the New and Alamo Rivers, was quantified by Wahlin et al. (1997) and used to assign accuracy to $\mathrm{ET}_{c}$ wB. Accuracy of All-American canal inflow was $\pm 2.5 \%$ on an annual basis $(95 \%$ confidence), which is considered to be very good. The uncertainty of canal inflow, however, contributed about $50 \%$ to total variance in the final $\mathrm{ET}_{c}$ wB estimate, due to its large magnitude. Subsurface outflows from IID are relatively very small (less than $0.3 \%$ of project inflows), so that they contributed only a small amount to uncertainty in $\mathrm{ET}_{c}$ WB.

Because there is high value placed on IID water by competing uses, there is substantial interest in and potential conflict related to studies of ET and water balances for IID. Unfortunately, conflicts can require legal proceedings for resolution. Confidentiality issues associated with current and future legal proceedings preclude identifying volumes of ET data computed for IID. Rather, all ET data and calculations are presented in terms of millimeters per day ${ }^{-1}$ over the irrigated area of the district. Annual $\mathrm{ET}_{c}$ volumes are reported in terms of relative volumes scaled to an undisclosed scaling factor. Relative differences and statistics are correct as reported.

\section{Results}

The accuracy of computed $\mathrm{ET}_{c}$ WB was estimated to be $\pm 6 \%$ at the $95 \%$ confidence level for annual periods based on WST (1998) and recent reanalyses (Wahlin et al. private communication 2004). The $\mathrm{ET}_{c}$ WB accuracy estimates are based on uncertainties associated with measurements of surface inflows and outflows (Wahlin et al. 1997, private communication 2004), estimation of subsurface inflows, and outflows, and prediction of effective precipitation. The procedure used to calculate confidence intervals of water balance components and $\mathrm{ET}_{c} \mathrm{WB}_{\mathrm{WB}}$ is described by Clemmens and Burt (1997). Accuracy of computed $\mathrm{ET}_{c} \mathrm{WB}$ for monthly time steps was greater than the $\pm 6 \%$ for annual volumes because of the effect of increased uncertainty in monthly $\Delta S$ and reduced degrees of freedom (numbers of observations) in water measurements. Monthly confidence intervals for $\mathrm{ET}_{c \text { WB }}$ could not be quantified due to lack of confidence in prediction of change in water storage in soil and in-project reservoirs from month to month. Our perception is that our accuracy of monthly $\mathrm{ET}_{c}$ wB is in the range of 10-20\%. With perfect knowledge of $\Delta S$, confidence for monthly $\mathrm{ET}_{c}$ wB would be about $6.5 \%$.

On average, annual predictions for $K_{c}$-based $\mathrm{ET}_{c}$ (labeled here as $\mathrm{ET}_{c K c}$ ) using the FAO-56 dual $K_{\mathrm{cb}}+K_{e}$ approach, before any adjustment, exceeded $\mathrm{ET}_{c}$ wB by about $8 \%$ over the 7 year period of 1990-1996. The $8 \%$ difference from $\mathrm{ET}_{c}$ wB exceeds the $95 \%$ confidence interval of $\mathrm{ET}_{c} \mathrm{WB}$, which is $\pm 6 \%$, and thus is considered to be statistically highly significant.

The $8 \%$ overprediction probably stemmed primarily from using $K_{c}$ values from FAO-56 and California publications that are considered to represent potential levels of ET under pristine growing conditions (optimum vegetation density, full water supply, no salinity, high agronomic management). Other sources of the higher prediction by $\mathrm{ET}_{c K c}$ are associated with error or bias in $\mathrm{ET}_{0}$, differences between $K_{c}$ of crop varieties grown in IID and $K_{c}$ values in the literature, errors caused by $K_{c}$ curve construction, error in estimated irrigation schedules, error in prediction of evaporation from wet soil, error in crop acreage identification, and error in $\mathrm{ET}_{c \mathrm{WB}}$, to which $\mathrm{ET}_{c K c}$ is compared. Crops in the study area were not always in full pristine condition, as described in more detail later. Yields and $\mathrm{ET}_{c}$ from some fields within large projects such as IID are commonly below potential levels due to occasional water stresses between irrigations, occasional suboptimal planting densities, or plant vigor, occasional suboptimal fertility, salinity, nonuniformity of irrigation and soils, disease, insect pressures, and tillage traffic. Delays in forage crop removal can also reduce $\mathrm{ET}_{c}$ from portions of fields lying beneath windrows.

In general, estimates of potential $\mathrm{ET}_{c K c}$ predicted by the dual method followed $\mathrm{ET}_{c}$ wB closely from month to month and year to year, as shown in Fig. 3. Trends between winter and summer in $\mathrm{ET}_{c}$ WB were captured very well by $\mathrm{ET}_{c}$ Kc . The $\mathrm{ET}_{0}$ plotted in Fig. 3 shows the potential for evaporating water if the entire project were planted to the grass reference. Volumetric values in Fig. 3 (and Fig. 4) have been scaled using a nondisclosed scaling factor that is significantly different from 1.0 in order to maintain a degree of confidentiality of the data for the district.

Values for monthly $\mathrm{ET}_{c}$ wB dropped off significantly in November during many years when monthly $\Delta S$ was included in Eq. (2) (Fig. 3). Substantial areas of wheat are preirrigated in IID during November. This was considered in the $\mathrm{ET}_{c} K_{c}$ daily water balance procedure when estimating $\Delta S$. However, the positive change predicted for $\Delta S$ in November for wheat may have been overestimated, since the estimation procedure assumed that each crop followed itself, so that typically large depletions of soil water at harvest of wheat were assumed to be replaced during the preirrigation of wheat in November. Under normal rotations practiced in IID, wheat would follow some other crop that would have had smaller soil water depletion at harvest, and thus wheat would have had a lower depletion at the time of preirrigation. The potentially overpredicted $\Delta S$ for wheat caused underprediction in the $\mathrm{ET}_{c}$ wB for November as evidenced in Fig. 3. When $\Delta S$ was set at zero, $\mathrm{ET}_{c}$ wB followed the $\mathrm{ET}_{c K c}$ prediction closely for all years.

Table 3 summarizes the standard error of estimate (SEE), computed as the root mean square difference between ET $_{c K c}$ and $\mathrm{ET}_{c}$ wB using $n-2$ degrees of freedom. The SEE represents differences after least-squares regression between $\mathrm{ET}_{c K c}$ and $\mathrm{ET}_{c}$ WB. The SEE averaged about $16 \%$ of mean monthly $\mathrm{ET}_{c}$ over all monthly time steps, but only $3.4 \%$ for annual periods (first line of Table 3). These comparisons used values for $\mathrm{ET}_{c}$ wB following adjustment for monthly soil moisture change $(\Delta S)$ within the project. When $\Delta S$ was assumed zero from month to month, the $\mathrm{SEE}$ between $\mathrm{ET}_{c K c}$ and $\mathrm{ET}_{c}$ WB decreased to $13 \%$ over all monthly time steps, although the $\mathrm{ET}_{c K c}$ values predicted $11 \%$ higher than $\mathrm{ET}_{c \mathrm{WB}}$, on average, for monthly time steps and $9 \%$ higher for annual (line two of Table 3). The lower SEE for $\Delta S$ $=0$ indicates more similarity in month to month trends between $\mathrm{ET}_{c K c}$ and $\mathrm{ET}_{c}$ WB when monthly estimated $\Delta S$ was not considered. This may suggest significant error in the $\Delta S$ prediction process applied during this study.

\section{Adjustment of $K_{c}$-Based Evapotranspiration}

As previously noted, some fields or areas of fields were observed to show evidence of some reduction in vegetation mass and vigor. Reductions in vegetation amount are generally associated with reductions in evapotranspiration because of effects of reduced leaf area and water or salt induced stresses (Doorenbos and Kassam 1979; Allen et al. 1998). A visual rating of field appearances was made using a composite color aerial photo of the project on a gridded overlay. The visual rating indicated that approximately $1.6 \%$ of cropped area was visually bare or not farmed. Reported 

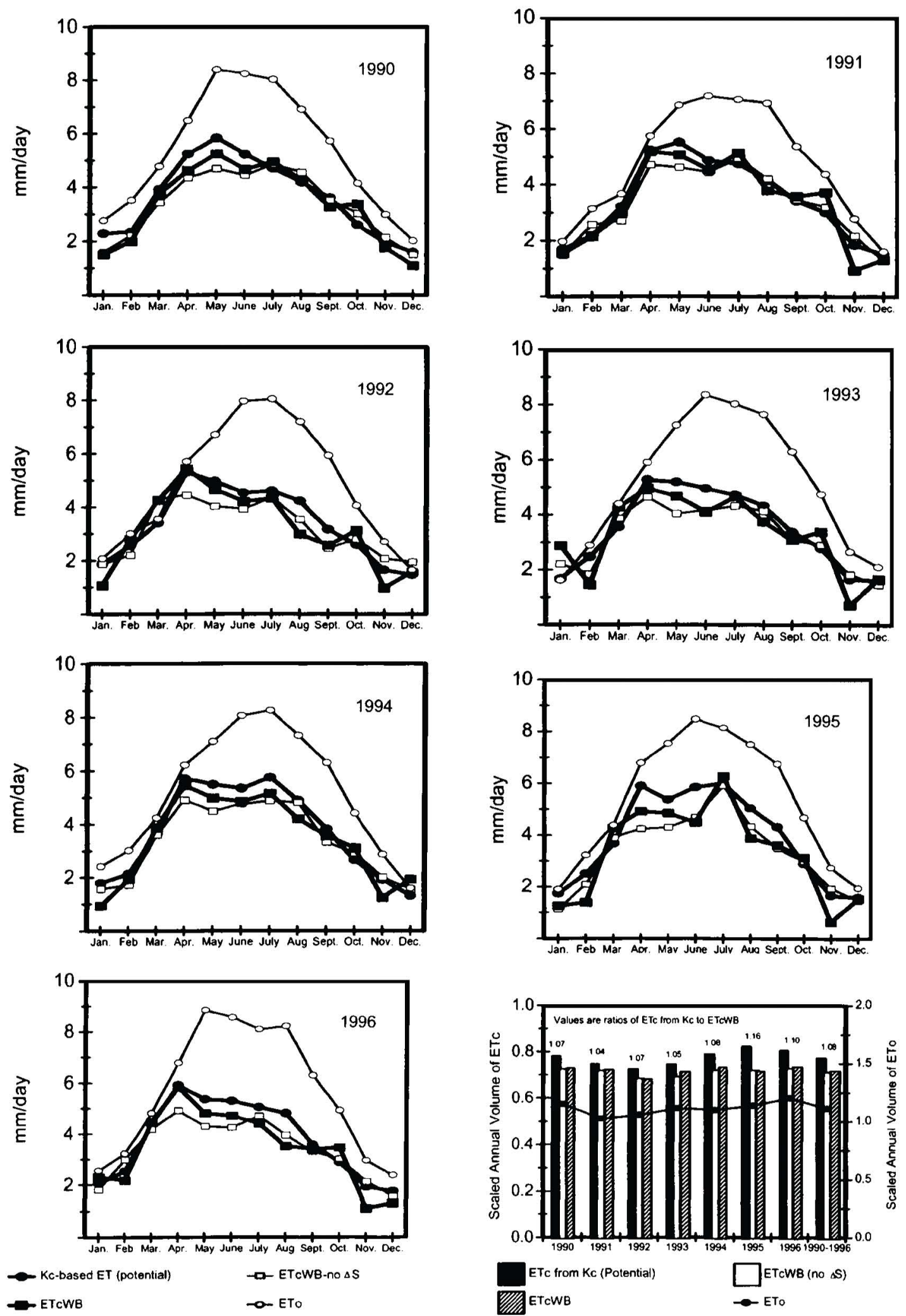

Fig. 3. Monthly grass reference evapotranspiration $\left(\mathrm{ET}_{0}\right)$, potential $K_{c}$-based evapotranspiration, and crop evapotranspiration from water balance computed with change in monthly soil water storage water balance $\left(\mathrm{ET}_{c} \mathrm{wB}_{\mathrm{B}}\right.$ ) and without change in $\Delta S$ ( $\mathrm{ET}_{c}$ wB no $\Delta S$ ) and annual summary for irrigated farmland in the Imperial Irrigation District, 1990-1996 period 

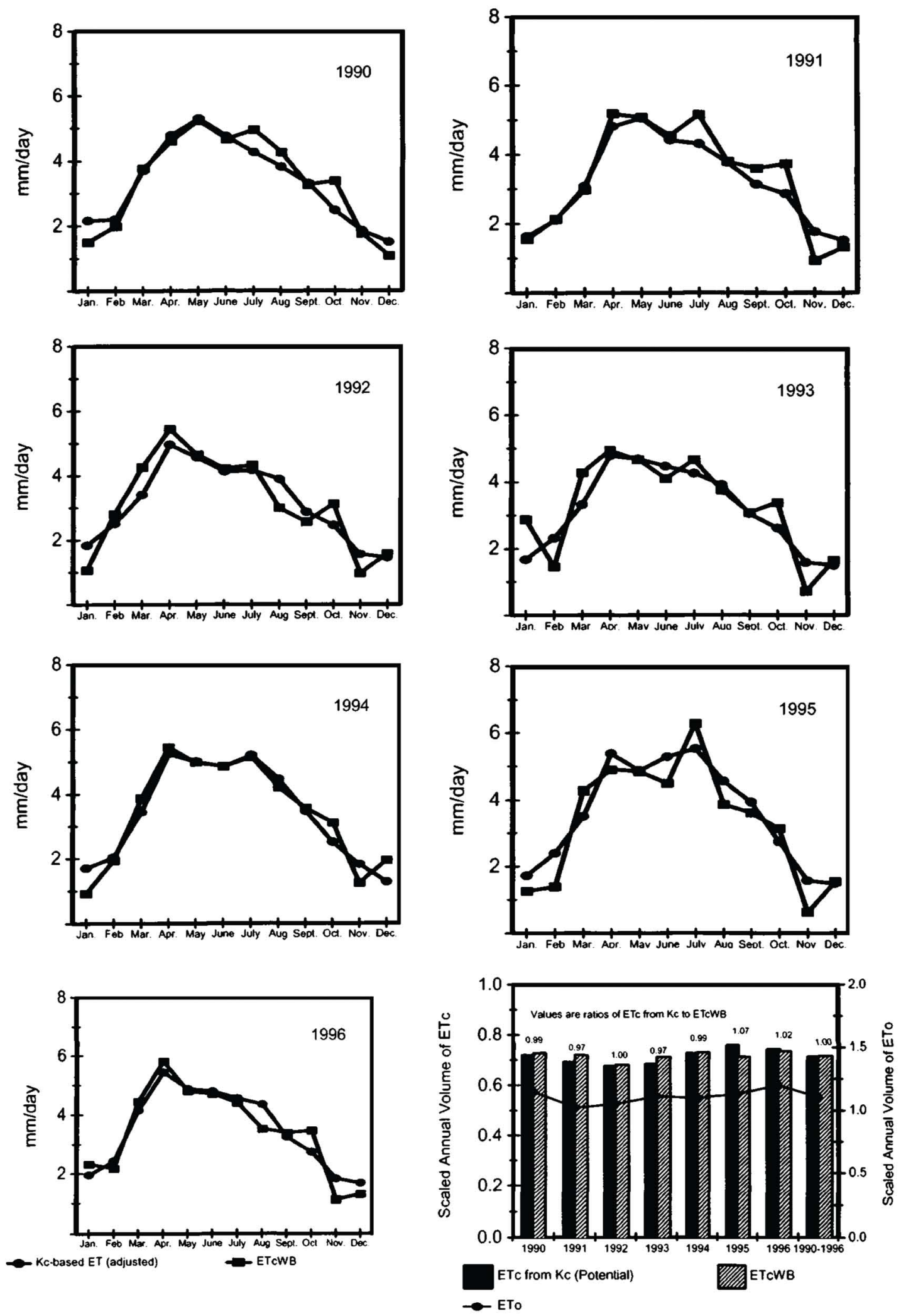

Fig. 4. Monthly $K_{\mathrm{c}}$-based evapotranspiration predicted following approximately $8 \%$ downward adjustment and crop evapotranspiration from water balance with adjustment for monthly change in soil water and annual summary for irrigated farmland in the Imperial Irrigation District, 1990-1996 period 
Table 3. Adjustment Factors Applied to Evapotranspiration $(\mathrm{ET})_{c} \mathrm{Kc}$ Computations (in Addition to 6\% Reduction Based on Visual Rating of Crops) to Force Agreement to Evapotranspiration from Water Balance for the Imperial Irrigation District

\begin{tabular}{lccccc}
\hline & $\begin{array}{c}\text { Alfalfa } \\
\text { hay }\end{array}$ & Bermuda & Sudan & $\begin{array}{c}\text { Sugar } \\
\text { beets }\end{array}$ & $\begin{array}{c}\text { Permanent } \\
\text { pasture }\end{array}$ \\
\hline January & 1.00 & 1.00 & 1.00 & 1.00 & 0.95 \\
February & 1.00 & 1.00 & 1.00 & 1.00 & 0.95 \\
March & 1.00 & 1.00 & 1.00 & 1.00 & 0.95 \\
April & 0.95 & 0.95 & 0.97 & 0.97 & 0.90 \\
May & 0.95 & 0.95 & 0.97 & 0.97 & 0.90 \\
June & 0.95 & 0.95 & 0.97 & 0.97 & 0.90 \\
July & 0.95 & 0.95 & 0.97 & 0.97 & 0.90 \\
August & 0.95 & 0.95 & 0.97 & 0.97 & 0.90 \\
September & 0.95 & 0.95 & 0.97 & 0.97 & 0.9 \\
October & 1.00 & 1.00 & 1.00 & 1.00 & 0.90 \\
November & 1.00 & 1.00 & 1.00 & 1.00 & 0.95 \\
December & 1.00 & 1.00 & 1.00 & 1.00 & 0.95 \\
Resulting & 0.96 & 0.96 & 0.97 & 0.98 & 0.90 \\
\end{tabular}

annual

factor $^{\mathrm{a}}$

$\overline{{ }^{\mathrm{a}} \text { Computed by weighting individual months according to } \mathrm{ET}_{c \mathrm{Kc}} \text { for that }}$ month.

field acreages were reduced accordingly during conversion of $K_{c}$-based $\mathrm{ET}_{c}$ into volumes. The overlay assessment also indicated that on average, crops in the project were only at about $88 \%$ "vigor" (relative to $100 \%$ ), based on variations noted in color within fields, presence of brown spots, and visible areas of low plant density. The vigor reduction appeared to be distributed over all crop types.

The visual rating was used to reduce potential $\mathrm{ET}_{c} K_{c}$ by a constant $6 \%$ over all months and years and crops using an approximate application of Eqs. (94) and (96) of Allen et al. (1998), where reduction in visual appearance or vigor was assumed to approximately equal reduction in fraction of cover. Therefore, relative $\mathrm{ET}_{c}$ became approximately proportional to the square root of vigor (0.88). This adjustment resulted in a $6 \%$ reduction recommended to $\mathrm{ET}_{c K c}$ based on visual appearance, alone. This adjustment was assumed to account for the general reduction in $\mathrm{ET}_{c}$ caused by the various and occasionally suboptimal agronomic practices that occurred over essentially all crops due to various causes.

Besides the $6 \%$ reduction over all crops and months, additional reductions were made to five field crops of relatively lower value that were judged to be more subject than others to various agronomic, salinity, water and management stresses. In addition to the $6 \%$ reduction, ET from crops alfalfa, Bermuda, Sudan, sugar beet, and permanent pasture was multiplied by further reduction factors that changed by month, with largest reductions during summer. Factors are summarized in Table 4. The same factors were applied each year. None of the additional factors were large for any particular crop, ranging from a $2 \%$ reduction for sugar beets to a $10 \%$ reduction for pasture. The variation of the reduction among the crops was subjective and was based on relative economic value of the crops, relative sensitivity to water stress and salinity, and comments from IID staff regarding which crops were more prone to water shortage by farm management when canal lateral discharges were constrained by channel capacity. Reductions were applied during summer because of the higher expected incidence of water stress between irrigations and salinity-induced stress during high ET periods. Episodes of water shortage due to water supply limitations to and within the district were considered by IID staff to be relatively infrequent and to have minor impact on $\mathrm{ET}_{c} \mathrm{WB}_{\mathrm{B}}$ and crop yield. The additional adjustment factors in Table 4 reduced $\mathrm{ET}_{c} K_{c}$ from the FAO-56 dual $K_{\mathrm{cb}}+K_{e}$ procedure by an additional $2 \%$ annually over the district so that adjusted $\mathrm{ET}_{c K c}$ computations agreed, on average, with $\mathrm{ET}_{c}$ wB.

Following the imposed reduction to $\mathrm{ET}_{c K c}$, annual ratios of adjusted $\mathrm{ET}_{c K c}$ to $\mathrm{ET}_{c}$ wB ranged from 0.97 to 1.07 among years and averaged 1.00 as illustrated in Fig. 4, bottom right. The $\mathrm{SEE}=3.4 \%$ for annual comparisons implies that the $K_{c}$-based ET approach, when used with the assumed $\mathrm{ET}_{c}$ adjustment factors and when applied following FAO-56 dual procedure, can predict within $\pm 4 \%$ of actual annual $\mathrm{ET}_{c}$ for any specific year, as represented by the water balance, about $68 \%$ of the time. The procedure would predict within $\pm 7 \%$ of actual annual $\mathrm{ET}_{c}$ about $95 \%$ of the time. As shown previously, confidence intervals were significantly larger for monthly $\mathrm{ET}_{c}$ estimates and were caused by computational uncertainties and variation in growth stages and dates, timing of irrigations within the large field populations within any particular month, and monthly change in projectwide soil water content. These uncertainties largely cancelled over annual periods.

Monthly values for adjusted $\mathrm{ET}_{c K c}$ agreed relatively closely with monthly measured $\mathrm{ET}_{c}$ WB as shown in Fig. 4, especially for some years, such as 1994 and 1996, where the $\mathrm{ET}_{c K c}$ followed the same trends and had the same magnitude as monthly $\mathrm{ET}_{c}$ WB. The close agreement indicates that use of relatively constant adjustment factors from month to month was reasonable. The $r^{2}$

Table 4. Monthly and Annual Ratios of $K_{c}$ Evapotranspiration $(E T)_{c}$ Estimates to Evapotranspiration from Water Balance and Standard Errors of Estimate (SEE) Under Various Conditions of Relaxation in Detail Used to Predict $K_{c}$

\begin{tabular}{|c|c|c|c|c|}
\hline \multirow[b]{2}{*}{ Method for $\mathrm{ET}_{c K c}$} & \multicolumn{2}{|c|}{ Monthly } & \multicolumn{2}{|c|}{ Annual } \\
\hline & $\begin{array}{c}\text { Ratio } \\
\mathrm{ET}_{c K c} \text { to } \\
\mathrm{ET}_{c} \mathrm{WB}\end{array}$ & $\begin{array}{c}\text { SEE } \\
\text { after } \\
\text { regression } \\
(\%)\end{array}$ & $\begin{array}{c}\text { Ratio } \\
\mathrm{ET}_{c K c} \text { to } \\
\mathrm{ET}_{c} \mathrm{WB}\end{array}$ & $\begin{array}{c}\text { SEE } \\
\text { after } \\
\text { regression } \\
(\%)\end{array}$ \\
\hline$K_{\mathrm{cb}}+K_{e}$ - potential & 1.08 & 16.0 & 1.08 & 3.4 \\
\hline$K_{\mathrm{cb}}+K_{e}$-potential, no $\Delta S$ & 1.11 & 13.0 & 1.09 & 3.0 \\
\hline$K_{\mathrm{cb}}+K_{e}$-adjusted & 0.99 & 15.4 & 1.00 & 3.4 \\
\hline$K_{c \text { mean }}$-potential, using actual cropping dates & 1.03 & 16.3 & 1.00 & 3.4 \\
\hline$K_{c \text { mean }}$ - potential, using average cropping dates for each year & 1.02 & 16.9 & 1.00 & 4.0 \\
\hline$K_{c \text { mean }}$-potential, using cropping dates from FAO-56 & 1.00 & 18.1 & 0.98 & 4.8 \\
\hline
\end{tabular}


between monthly values over the 7 year study period $(n=84)$ was 0.89 and the SEE for the average monthly $\mathrm{ET}_{c}$ was $15 \%$ of the average monthly $\mathrm{ET}_{c}$ (Table 3, line 3) and 3.4\% for total annual $\mathrm{ET}_{c}$.

The $\mathrm{SEE}=15 \%$ and ratio of $\mathrm{ET}_{c K c}$ to $\mathrm{ET}_{c}$ wB $_{\text {of }} 0.99$ (Table 3 ) suggests that adjusted $\mathrm{ET}_{c K c}$ was capable of predicting monthly $\mathrm{ET}_{c}$ wB to within $\pm 15 \%$ only $68 \%$ of the time on a monthly basis for all of IID. This statistic presumes that there was no error in the $\mathrm{ET}_{c \text { WB }}$ measurements or in the $\Delta S$ calculations. In actuality, the estimated $\pm 10-20 \%$ confidence intervals for monthly $\mathrm{ET}_{c} \mathrm{WB}$ would imply that the true confidence interval for the adjusted monthly $\mathrm{ET}_{c K c}$ could be $\pm 25 \%$. It also implies that true accuracy of $\mathrm{ET}_{c K c}$ could be better than $15 \%$, if monthly $\mathrm{ET}_{c}$ wB had been computed with more certainty. The implication of the uncertainty in $\mathrm{ET}_{c K c}$ is that monthly diversion requirements for IID can only be predicted to within $\pm 15 \% 68 \%$ of the time if based on $\mathrm{ET}_{c K c}$, even when cropping acreages and planting and harvest dates are known for each year, and assuming that $\mathrm{ET}_{0}$ and expected precipitation for the coming month are known perfectly. The prediction accuracy is only $\pm 30 \%$ at $95 \%$ confidence. These large confidence intervals would appear to preclude using $\mathrm{ET}_{c K c}$ as the sole means to predict or forecast monthly water demands for IID for purposes of specifying Hoover Dam releases.

\section{Impact of Less Detail in Computation of $\boldsymbol{K}_{c}$}

A primary objective for this study was to estimate ET $_{c K c}$ as accurately as possible. Therefore, the dual crop coefficient procedure was applied so that impacts of evaporation from wetted soil could be more accurately estimated. In addition, recorded mean planting and harvest dates for each year were used to refine $K_{c}$ curves. Often, however, relatively rapid estimates of $\mathrm{ET}_{c K c}$ are needed with insufficient time to apply the dual $K_{c}$ approach or to monitor cropping dates. These rapid assessments may require using the so-called "mean" or "singular" $K_{c}$ curves of FAO or other publications. The mean $K_{c}$ curves include implicit amounts of soil evaporation for assumed wetting frequencies, eliminating the need for separate calculation of evaporation (Jensen et al. 1990). Of course, the $K_{c \text { mean }}$ curves represent only "average" conditions of soil wetting by irrigation and/or precipitation, so that the potential for error increases with this method.

A sensitivity analysis was conducted to assess the impact of level of perceived accuracy of the $K_{c}$-based $\mathrm{ET}_{c}$ procedure on a project scale. This was done by reducing the detail of evaporation and cropping information. Successive computations of $\mathrm{ET}_{c K c}$ were made where the detail of knowledge of planting and harvest dates was relaxed. In one run, recorded cropping dates based on IID summaries were used, but the dates were averaged over all 7 years. In a following run, average dates for planting and harvest for each crop were taken directly from Table 11 of FAO-56 (Allen et al. 1998) rather than using dates based on local information. This practice is recommended against in FAO-56 (see page 108) because of the general nature of the dates in Table 11 and the strong likelihood that they may not describe local conditions. This analysis was undertaken to obtain an idea of the extent of error that could be introduced into project-scale $\mathrm{ET}_{c K c}$ when using "off-the-shelf" values for both $K_{c \text { mean }}$ and for planting and harvest dates. One caveat of this latter analysis is that cropping dates are listed in Table 11 of FAO-56 for the specific climate and region as the study area (i.e., "California desert") for many of the crops grown. These entries were introduced into the FAO-56 table by the lead author during its preparation and were based on average cropping dates noted for IID. Therefore, using these same dates from FAO-56 does not provide a completely independent assessment of the impact of using generalized cropping dates. Results for other regions would probably be poorer.

Table 4 summarizes ratios of monthly $\mathrm{ET}_{c} \mathrm{Kc}_{c}$ to $\mathrm{ET}_{c}$ wB under the various levels of reduced detail. The first three entries have been discussed. These represent applications of $K_{\mathrm{cb}}+K_{e}$ using the FAO-56 procedures where mean cropping dates were used each year. The "potential" label indicates that $\mathrm{ET}_{c K c}$ was not adjusted to local conditions and therefore represents potential or pristine agronomic and water management conditions. The "No $\Delta S$ " label denotes comparison between potential $K_{\mathrm{cb}}+K_{e}$ based $\mathrm{ET}_{c K c}$ and $\mathrm{ET}_{c} \mathrm{WB}$ assuming no monthly or annual change in stored soil water over the project. As discussed previously, annual and monthly ratios of $\mathrm{ET}_{c K c}$ averaged $8-11 \%$ higher than $\mathrm{ET}_{c}$ WB (row 1 of Table 4).

The fourth row of Table 4 represents the application where $K_{c \text { mean }}$ curves from Table 12 of FAO-56 were used rather than the dual $K_{\mathrm{cb}}+K_{e}$, so that no daily soil water balance was necessary and no separate calculation of evaporation from soil was made. Values shown are "potential" values with no adjustment. It is interesting, and somewhat unexpected, that potential $\mathrm{ET}_{c} K_{c}$ predicted using $K_{c}$ mean averaged only 3\% higher than $\mathrm{ET}_{c}$ WB for monthly periods and was the same as $\mathrm{ET}_{c} \mathrm{WB}_{\mathrm{W}}($ ratio $=1.00)$ for annual periods. The smaller $\mathrm{ET}_{c K c}$ using the $K_{c \text { mean }}$ method suggests that the $K_{c \text { mean }}$ values from FAO-56 include or imply lower magnitudes of evaporation from soil than were predicted by the $K_{\mathrm{cb}}+K_{e}$ procedure for the IID project. The $\mathrm{ET}_{c K c}$ estimates by the $K_{\mathrm{cb}}+K_{e}$ procedure are considered to be more correct, following adjustment, even though the potential values deviated further

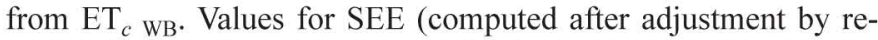
gression) were the same between the dual and $K_{\text {mean }}$ calculations, suggesting that the month to month and year to year deviation of $\mathrm{ET}_{c K c}$ from $\mathrm{ET}_{c \text { WB }}$ for $K_{c \text { mean }}$ were similar to those for the dual method.

The higher $\mathrm{ET}_{c K c}$ by the $K_{\mathrm{cb}}+K_{e}$ procedure as compared to using $K_{c \text { mean }}$ curves stemmed from three primary chacteristics of IID and application of the dual method: (1) the assumption of Stage 3 evaporation from the cracking soils of IID predicted a relatively large amount of evaporation from wet soil for field crops; (2) assumed frequent irrigation of vegetable crops caused prediction of a relatively large amount of evaporation from wet soil for the lighter soils (some of this increase is implicit to $K_{c \text { mean }}$ values); and (3) the application of the dual method was made to complete calendar years, including periods between crops. Therefore, evaporation losses from precipitation and irrigation events during noncropping periods (where irrigation for leaching and soil preparation is practiced) were captured. This evaporation was not included in application of the $K_{c}$ mean method, which was applied in the traditional way, where $\mathrm{ET}_{c}$ before planting and after harvest was assumed zero. This is an erroneous assumption, but is common practice, due to lack of knowledge of accurate values to use for $K_{c \text { mean }}$ outside growing periods. Further, the $K_{c \text { mean }}$ values from Table 12 of FAO-56 were not adjusted to improve agreement with $K_{c}$ from Univ. of California publications as was done for the dual method (i.e., $\left.K_{\mathrm{cb}}\right)$. However, adjustments made to $K_{\mathrm{cb}}$ were relatively minor and were in different directions for different crops as shown in Table 1 .

The nongrowing season evaporation losses from special irrigations were estimated by the dual method to be about $2-3 \%$ of annual $\mathrm{ET}_{c}$ from the project (WST 1998). Accounting for this somehow in the $K_{c \text { mean }}$ estimates would have increased its total prediction by this amount. 
The fifth row in Table 4 is similar to the fourth row except that the same dates for planting and harvest of crops were applied each year, based on averages for the 7 year period. In this application, the mean ratios of $\mathrm{ET}_{c K c}$ to $\mathrm{ET}_{c}$ WB did not change, but SEE increased slightly, especially for annual totals (from 3.4 to $4.0 \%$ ). The increase in error was due to the lower precision in specifying beginning and termination of growing periods. It is important to point out that nearly $40 \%$ of the acreage in IID was alfalfa during 1990-1996. Alfalfa is a perennial crop having yearround growth, so that knowledge of local cropping dates was relatively unimportant for it.

As a final sensitivity analysis, standard values for lengths of growing periods from Table 11 of FAO-56 were used to describe planting and harvest dates for annual crops each year (row six of Table 2). Ratios of $\mathrm{ET}_{c K c}$ to $\mathrm{ET}_{c} \mathrm{WB}$ for this application did not deviate much from 1.00, indicating relatively small impact on a project scale by this relaxation in data requirements. Values for SEE after regression increased by a small amount for monthly values (from 16.3 to $18.1 \%$ ) and SEE increased by about $50 \%$ for annual values (from 3.4 to $4.8 \%$ ), which could be considered to be significant.

The results of the sensitivity analyses indicate that using dates for planting and harvest specific to the local area and year do improve estimates when predicting $\mathrm{ET}_{c}$ for a large irrigation project. However, the increase in accuracy in this application was not large due to the mostly random distribution of planting dates coupled with the large population of fields. In addition, the dates used from FAO-56 (for "California desert") agreed closely with IID averages. Similarly, using $K_{c}$ mean where effects of $K_{e}$ are implicit did not substantially degrade predictions. However, use of $K_{c}$ mean did reduce the absolute magnitudes of predicted $\mathrm{ET}_{c}$ by $5 \%$ for monthly estimates and by $8 \%$ on an annual basis. About one-half of this reduction was due to the lack of accounting for off-season evaporation from preplant and leaching irrigations.

\section{Impact of Adjusting FAO-56 $K_{c}$ to California Publications and Using CIMIS Reference Evapotranspi- ration Rather than FAO-56 Penman-Monteith-Based Reference Evapotranspiration}

Annual $\mathrm{ET}_{0}$ computed by the FAO-56 Penman-Monteith (PM) method (applied daily) averaged only $2 \%$ lower than $\mathrm{ET}_{0}$ used in the analyses reported in this paper, which represented CIMIS Penman-based $\mathrm{ET}_{0}$ with net radiation by the method of FAO-56. Therefore, the impact of using $\mathrm{ET}_{0}$ computed by the FAO-56 PM rather than $\mathrm{ET}_{0}$ used in this study would have been small, and would have reduced prediction of $\mathrm{ET}_{c K c}$ by only about $2 \%$.

Some FAO-56 $K_{\mathrm{cb}}$ values were adjusted, as summarized in Table 1, to reflect $K_{c}$ values common to California literature. Adjustments were small and impacted predicted annual ET from the study area by less than a few percent. It is noted that FAO- $56 K_{c} \mathrm{~s}$ have been recommended by ASCE (2002) for application with both the FAO-56 PM ET E $_{0}$ and CIMIS ET F $_{0}$ methods with no adjustment. A priori adjustments to FAO-56 $K_{c}$ were made in this study to better test accuracy of California-based $K_{c}$ s, but using the FAO-56 dual $K_{c}$ procedure.

\section{Conclusions}

When applied to a large 200,000 ha irrigation project in southern California, the FAO-56 based dual crop coefficient method produced relatively accurate estimates of projectwide ET on a monthly time step. The potential ET predicted by the $K_{c}$ method averaged $8 \%$ higher than ET determined by a water balance, but trends from month to month and year to year were very similar. Applications with a more simple "mean" crop coefficient predicted about 5\% lower than did the dual crop coefficient method, indicating that predictions of evaporation by the dual method were greater than those implied in the mean $K_{c}$ values. Over all, the $K_{c}$-based ET method proved to provide consistent and relatively accurate predictions of crop ET on a project-wide basis. However, perceived error in monthly ET predicted by the $K_{c}$-based method would limit its usefulness as the primary variable in predicting reservoir releases. It may, however, be useful in adjusting release requests that are based primarily on needs or usage of prior years.

The findings of this study provide some indication of expected performance of the $K_{c}$-based method elsewhere. However, $K_{c}$ and ET are substantially impacted by water availability, water and crop management, climate, salinity and drainage control, and soil. Thus, one must exercise caution in transferring these results and prediction accuracies to other studies.

The results of the sensitivity analyses indicate that using dates for planting and harvest specific to the local area and year do improve estimates when predicting $\mathrm{ET}_{c}$ for a large irrigation project. However, the increase in accuracy for large areas is not substantial due to the mostly random distribution of planting dates coupled with large population of fields.

\section{Acknowledgments}

The Imperial Irrigation District (IID) of southern California provided financial and technical support for this study in addition to vast amounts of cropping and water use data. The project is commended for its long-standing program of water measurement and data reporting.

\section{References}

Allen, R. G. (1996). "Assessing integrity of weather data for use in reference evapotranspiration estimation." J. Irrig. Drain. Eng., 122(2), 97-106.

Allen, R. G., Pereira L. S., Raes, D., and Smith, M. (1998). "Crop evapotranspiration: Guidelines for computing crop water requirements." United Nations Food and Agriculture Organization, Irrigation and Drainage Paper 56, Rome.

Allen, R. G., Pereira, L. S., Smith, M., Raes, D., and Wright, J. L. (2005). "The FAO-56 dual crop coefficient method for predicting evaporation from soil and application extensions." J. Irrig. Drain. Eng., 131(1), $2-13$.

American Society of Civil Engineers (ASCE). (2002). The ASCE standardized equation for calculating reference evapotranspiration, Environment and Water Resources Institute of ASCE, New York.

Burt, C. M., et al. (1997). "Irrigation performance measures: Efficiency and uniformity." J. Irrig. Drain. Eng., 123(6), 423-442.

Clemmens, A. J., and Burt, C. M. (1997). "Accuracy of irrigation efficiency estimates.” J. Irrig. Drain. Eng., 123(6), 443-453.

Doorenbos, J., and Kassam, A. H. (1979). "Yield response to water." United Nations Food and Agriculture Organization Irrigation and Drainage Paper No. 33, Rome.

Doorenbos, J., and Pruitt, W. O. (1977). "Crop water requirements." United Nations FAO Irrigation and Drainage Paper No. 24, (revised), Rome.

Droogers, P., and Bastiaanssen, W. (2002). "Irrigation performance using hydrological and remote sensing modeling." J. Irrig. Drain. Eng., 
128(1), 11-18.

Gochis, D. J., and Cuenca, R. H. (2000). "Plant water use and crop curves for hybrid poplars.” J. Irrig. Drain. Eng., 126(4), 206-214.

Hawkins, R. H., Hjelmfelt, A. T., and Zevenbergen, A. W. (1985). "Runoff probability, storm depth, and curve numbers." J. Irrig. Drain. Eng., 111(4), 330-340.

Imperial Irrigation District (IID). (2002). Imperial Irrigation District Conservation and Transfer Project Final Environmental Impact Rep. and Habitat Conservation Plan; State Clearing House No. 9091142, Sacramento, Calif.

Imperial Irrigation District (IID). (2003). "Description of the project." 〈http://www.iid.com/water/works-delivery.html, accessed March, 2004.)

Jensen, M. E., Burman, R. D., and Allen, R. G., eds. (1990). "Evapotranspiration and irrigation water requirements." ASCE manuals and reports on engineering practice No. 70, New York, $360 \mathrm{pp}$.

Loeltz, O. J., Irelan, B., Robison, J. H., and Olmsted, F. H. (1975). "Geohydrologic reconnaissance of the Imperial Valley, California." U.S. Geol. Surv. Prof. Pap., 486-K, 1-54.

Molden, D., and Sakthivadivel, R. (1999). "Water accounting to assess use and productivity of water." Water Res. Dev., 15, 55-71.

Pruitt, W. O., Swan, B. D., Held, A., Sutton, B., Matista, A., and Hsiao, T. C. (1987). "Bowen ratio and Penman: Australian-California tests." Irrig. Systems for the 21st Century, Proc. Irrig. and Drain. Specialist Conf; ASCE, Portland, Ore., 149-158.

Setmire, J. G., Schroder, R. A., Densmore, J. N., Goodbred, S. L., Audet, D. J., and Radke, W. R. (1993). "Detailed study of water quality, bottom sediment and biota associated with irrigation drainage in the
Salton Sea area, California, 1988-1990." U.S. Geological Survey Water Resources Investigation Rep. No. 93-4014, Washington, D.C.

Snyder, R. L., Lanini, B. J., Shaw, D. A., and Pruitt, W. O. (1989a). "Using reference evapotranspiration (ETo) and crop coefficients to estimate crop evapotranspiration (ETc) for agronomic crops, grasses, and vegetable crops." Leaflet No. 21427, Cooperative Extension, Univ. of California, Berkeley, Calif.

Snyder, R. L., Lanini, B. J., Shaw, D. A., and Pruitt, W. O. (1989b). "Using reference evapotranspiration (ETo) and crop coefficients to estimate crop evapotranspiration (ETc) for trees and vines." Leaflet No. 21428, Cooperative Extension, Univ. of California, Berkeley, Calif.

Soil Conservation Service (SCS). (1972). National engineering handbook, Sec. 4, Chaps. 7-10, Washington, D.C.

Szilagyi, J., Katul, G. G., and Parlange, M. B. (2001). "Evapotranspiration Intensifies over the Conterminous United States." J. Water Resour. Plan. Manage, 127(6), 354-362.

Wahlin, B. T., Replogle, J. A., and Clemmens, A. J. (1997). "Measurement accuracy for major surface-water flows entering and leaving the Imperial Valley." WCL Rep. No. 23, Prepared for U.S. Water Conservation Laboratory, Phoenix, Water Resources Publications, LLC., 〈http://www.wrpllc.com〉

Water Study Team (WST). (1998). Imperial Irrigation District water use assessment for the years 1987-1996, Imperial Irrigation District, Imperial, Calif.

Zimmerman, R. P. (1981). Soil survey of Imperial County, California, Imperial Valley area, U.S. Dept. of Agriculture, Soil Conservation Service, Washington, D.C. 